\title{
Perbandingan Efektivitas Natrium Laktat dengan Manitol untuk Menurunkan Tekanan Intrakranial Penderita Cedera Kepala Berat
}

\author{
Muhammad Zafrullah Arifin, Ajid Risdianto \\ Departemen Bedah Saraf Fakultas Kedokteran Universitas Padjadjaran \\ Rumah Sakit Dr. Hasan Sadikin Bandung
}

\begin{abstract}
Abstrak
Peningkatan tekanan intrakranial masih menjadi penyebab utama kematian pada penderita cedera kepala. Penggunaan obat baru sebagai terapi osmosis diharapkan mampu menurunkan tekanan intrakranial. Penelitian prospektif, samar ganda, acak dilakukan terhadap 20 penderita cedera kepala berat di Unit Gawat Darurat (UGD) Rumah Sakit Dr. Hasan Sadikin Bandung selama bulan Februari-Juli 2009. Penderita dikelompokkan dalam 2 kelompok yang mendapat terapi manitol atau natrium laktat. Dilakukan pengukuran tekanan intrakranial, kadar laktat, kadar natrium, serta kalium sebelum dan sesudah terapi osmosis dengan uji Shapiro-Wilk untuk analisis distribusi dan uji t berpasangan atau uji Wilcoxon untuk perbandingan rata-rata mempergunakan program statistical products and solution services (SPSS). Kelompok natrium laktat mengalami penurunan tekanan intrakranial $(p<0,001)$ serta kenaikan kadar laktat $(p=0,035)$. Kelompok manitol mengalami penurunan tekanan intrakranial $(\mathrm{p}=0,005)$ dan perubahan kadar laktat $(\mathrm{p}=0,135)$. Kadar natrium dan kalium pada kedua kelompok tidak terdapat perubahan yang bermakna. Penurunan tekanan intrakranial kelompok manitol dan natrium laktat tidak berbeda bermakna $(\mathrm{p}=0,417)$. Kadar laktat antara kelompok natrium laktat dan manitol berbeda bermakna $(\mathrm{p}=0,016)$, yaitu kenaikan kadar laktat yang lebih tinggi pada kelompok natrium laktat. Simpulan, pemberian natrium laktat dan manitol sama efektifnya menurunkan tekanan intrakranial pada penderita cedera kepala berat. Pemberian natrium laktat meningkatkan kadar laktat secara bermakna dibandingkan dengan pemberian manitol. Tidak terdapat perbedaan bermakna kadar natrium dan kalium pada kedua kelompok penelitian. [MKB. 2012;44(1):26-31].
\end{abstract}

Kata kunci: Cedera kepala berat, manitol, natrium laktat, tekanan intrakranial

\section{Comparisson between Natrium Lactate and Mannitol Effectivity in Decreasing Intracranial Pressure in Severe Head Injury Patients}

\begin{abstract}
Increasing of intracranial pressure still a main cause of death in head injury patient. A new osmotic therapy probably an alternative to decrease intracranial pressure. A prospective randomized double blind study was done in 20 severe head injury in Dr. Hasan Sadikin Hospital Bandung emergency unit during February-July 2009. Subjects were divided in 2 groups, the first group was treated by natrium lactate and the second group was mannitol. We measured intracranial pressure, lactate concentration, potassium and natrium concentration before and after treatment. The statistical analysis were performed by using Shapiro-Wilk test for distribution analysis and paired t-test or Wilcoxon test for mean comparison using statistical products and solution services (SPSS) program. Intracranial pressure decreased in natrium lactate group $(p<0.001)$ with increased of lactate concentration $(p=0.035)$. In mannitol group we get a decreased in intracranial pressure $(\mathrm{p}=0.005)$, and in lactate concentration $(\mathrm{p}=0.135)$. No significant changed of potassium and natrium concentration in each group. No significant intracranial decrease for natrium lactate versus mannitol was apreciated $(\mathrm{p}=0.417)$, but a significant different in lactate concentration $(\mathrm{p}=0.016)$. We noticed lactate concentration in natrium lactate had a higher increase. In conclusions, we noticed a significant intracranial pressure decreased by manitol as same as natrium lactate treatment. Natrium lactate administration was increasing lactate concentration significantly than mannitol done. No significant difference in natrium and potassium was noticed in both groups. [MKB. 2012;44(1):26-31].
\end{abstract}

Key words: Intracranial pressure, mannitol, natrium lactate, severe head injury

Korespondensi: Dr. M. Z. Arifin, dr., Sp.BS, Departemen Bedah Saraf Fakultas Kedokteran Universitas Padjadjaran-Rumah Sakit Dr. Hasan Sadikin Bandung, jalan Pasteur 38 Bandung 40161, telepon (022) 78234311, mobile 085243524441, e-mail ajidrisdianto@yahoo.com 


\section{Pendahuluan}

Cedera kepala masih merupakan permasalahan kesehatan global sebagai penyebab kematian, disabilitas, dan defisit mental. ${ }^{1-4}$ Cedera kepala menjadi penyebab utama kematian disabilitas pada usia muda. ${ }^{2}$ Penderita cedera kepala sering kali mengalami edema serebri atau perdarahan intrakranial yang akan meningkatkan tekanan intrakranial (intracranial pressure/ICP). ${ }^{5}$

Saat ini fokus perawatan penderita cedera kepala pada usaha mengatasi tekanan tinggi intrakranial. ${ }^{6}$ Peningkatan tekanan intrakranial telah dikenal sebagai faktor yang sangat menentukan mortalitas dan morbiditas penderita cedera kepala. ${ }^{7}$ Tekanan intrakranial yang terkontrol mencegah perburukan cedera kepala sekunder sehingga penderita cedera kepala memiliki prognosis yang lebih baik. ${ }^{8}$

Terjadinya cedera kepala dapat menyebabkan gangguan autoregulasi tekanan perfusi otak dan menyebabkan otak tidak terlindungi dari perubahan hemodinamika tubuh. Terganggunya autoregulasi berpotensi meninggikan tekanan intrakranial. ${ }^{9}$

Manitol saat ini merupakan diuretika osmotika yang banyak digunakan sebagai obat pilihan untuk mengatasi tekanan tinggi intrakranial. ${ }^{5,6,10,11}$ Manitol merupakan diuretika osmotika utama yang digunakan untuk mengurangi edema serebri. ${ }^{4}$ Manitol menurunkan tekanan intrakranial dengan cara memindahkan cairan dari intraselular ke ruang intravaskular. ${ }^{4}$ Pemindahan cairan tersebut karena menaikkan gradient osmotik antara otak dan darah. ${ }^{6}$ Efek cepat manitol didapat dari perubahan keenceran darah yang akan menaikkan aliran darah otak serta oksigenasi otak yang menyebabkan vasokontriksi yang berujung pada penurunan tekanan intrakranial.,6

Efek samping manitol dapat menyebabkan diuresis cairan dan elektrolit sehingga terjadi hipotensi intravaskular yang dapat meningkatkan mortalitas penderita cedera kepala. ${ }^{12}$ Pemberian manitol jangka panjang dapat menyebabkan dehidrasi intravaskular, hipotensi, serta azotemia prerenal yang dapat berkembang menjadi gagal ginjal.

Larutan garam hipertonik mulai digunakan sebagai agen osmotik agar terjadi penurunan tekanan intrakranial. ${ }^{12,13}$ Pemberian larutan garam hipertonik pada hewan percobaan yang mengalami syok hemoragik mampu menurunkan tekanan intrakranial serta edema serebri, juga meningkatkan aliran darah otak dan pengantaran oksigen. ${ }^{3}$ Selain itu, beberapa penelitian klinis memperlihatkan larutan garam hipertonik mampu menurunkan tekanan intrakranial penderita cedera kepala dan mempersingkat masa rawat di Intensive Care Unit (ICU). Ware dkk. ${ }^{5}$ melaporkan penurunan tekanan intrakranial lebih lama pada pemberian garam $23,4 \%$ bolus intravena dibandingkan dengan pemberian manitol.

Natrium laktat hipertonik merupakan larutan hipertonik yang berisi natrium laktat, kalium klorida, dan kalsium klorida dalam konsentrasi fisiologis. Natrium laktat hipertonik dalam volume kecil selama kondisi hipovolemia pada penderita postoperasi jantung mampu meningkatkan curah jantung, penghantaran oksigen, keluaran urin, mengurangi asidosis metabolik, dan menjaga hemodinamik agar tetap stabil. Hasil tersebut lebih baik jika dibandingkan dengan pemberian kristaloid.

Beberapa penelitian menunjukkan pemberian infus laktat pada cedera kepala akan meningkatkan suplai glukosa yang akhirnya mempengaruhi hasil fungsional dan histologis. ${ }^{14}$ Laktat diduga menjadi sumber energi otak pada penderita yang mengalami cedera kepala maupun yang tidak, efek ini didapatkan dengan menaikkan konsumsi oksigen mitokondria. Laktat mampu menaikkan konsumsi oksigen mitokondria jaringan otak, sedangkan glukosa menjaga konsumsi oksigen mitokondria jaringan otak pada nilai yang stabil. ${ }^{14}$

Manitol menyebabkan diuresis cairan dan sejumlah elektrolit, ${ }^{12}$ terutama elektrolit natrium dan kalium yang akan terbuang. Peranan natrium dan kalium ini untuk stabilitas membran sel saraf dan berperan dalam komunikasi antar sel. Jumlah natrium dan kalium dalam batas normal diharapkan akan mampu mempertahankan kerja sel saraf dalam kondisi normal.

Penelitian ini dilakukan untuk membandingkan penurunan tekanan intrakranial dengan terapi konservatif manitol dan natrium laktat sebagai terapi osmosis, juga untuk membandingkan kadar laktat, natrium, dan kalium pada pemberian natrium laktat dan manitol.

\section{Metode}

Penelitian ini merupakan penelitian prospektif samar ganda teracak yang dilaksanakan di Rumah Sakit Dr. Hasan Sadikin Bandung bulan Februari-Juli 2009. Subjek penelitian penderita cedera kepala berat akut dengan waktu kejadian $\leq 8$ jam sebelum masuk rumah sakit. Glasgow coma scale (GCS) waktu masuk $\leq 8$ atau terjadi perburukan kondisi neurologis sebelum masuk rumah sakit. Gambaran computed tomography (CT) scan subjek penelitian menunjukkan edema serebri dengan atau tanpa kelainan lain yang tampak.

Kriteria eksklusi penelitian yaitu usia $<13$ tahun atau $>72$ tahun, wanita hamil, ada indikasi operasi, trauma multipel, dilatasi pupil bilateral, 
hipoksemia lama sebelum perawatan di rumah sakit, hipotensi arterial, inisial hipernatremia, penetrating head injury, serta penderita yang sudah mendapat terapi barbiturat, steroid ataupun osmoterapi.

Penderita yang masuk kriteria penelitian dilakukan pengukuran tekanan intrakranial, kadar laktat, natrium, dan kalium, kemudian secara acak mendapat terapi osmosis berupa manitol atau natrium laktat. Pengacakan dilakukan dengan cara mengambil dalam amplop yang tertutup. Terapi osmosis yang diberikan berupa $1,5 \mathrm{~mL} /$ $\mathrm{kgBB}$ manitol $20 \%$ atau natrium laktat yang diberikan selama 15-30 menit. Tiga puluh menit setelah pemberian infus terapi osmosis dilakukan pengukuran tekanan intrakranial, kadar laktat, natrium, dan kalium.

Natrium laktat yang dipergunakan pada penelitian ini yaitu totilac dengan osmolalitas $1.020 \mathrm{mOsm} / \mathrm{L}$ (Tabel 1).

Manitol yang digunakan yaitu manitol yang mempunyai konsentrasi 20\% dengan volume per botolnya $300 \mathrm{~mL}$ dan memiliki osmolalitas 1.160 $\mathrm{mOsm} / \mathrm{kg}$.

Posisi kepala penderita dielevasi $30^{\circ}$, prosedur rutin penanganan penderita cedera kepala berat. Intubasi penderita, oksigenasi adekuat, pemasangan naso gastric tube (NGT), pemantauan tanda vital, pemasangan saturasi oksigen, pemasangan kateter urin, pemeriksaan darah lengkap, dan analisis gas darah (AGD) dilakukan pada kedua kelompok penelitian.

Status neurologis penderita dinilai dengan mempergunakan GCS. Kerusakan otak dinilai dengan menggunakan CT-scan yang dilakukan segera setelah penderita masuk. Efektivitas terapi osmotik dinilai berdasarkan data awal sebelum terapi, kemudian 30 menit sesudah pemberian terapi osmosis. Jika penderita membutuhkan terapi lain untuk pertolongan, maka data awal diperoleh sebelum terapi sekunder diberikan.

Analisis efek pemberian terapi osmosis diukur dengan menilai tekanan intrakranial pada 30 menit sesudah pemberian manitol atau natrium laktat sesuai pengacakan.

Analisis statistik mempergunakan program SPSS dengan uji distribusi Shapiro-Wilk pada subjek yang sama dan memiliki distribusi normal dibandingkan dengan perbedaan rata-ratanya menggunakan uji t berpasangan, sedangkan yang tidak memiliki distribusi normal dipergunakan uji Wilcoxon. Data tekanan intrakranial pada kedua kelompok penelitian yang memiliki distribusi data normal diukur dengan menggunakan uji independent samples.

Penelitian ini telah mendapatkan ethical clearance dari Komite Etik Penelitian Kesehatan Fakultas Kedokteran Universitas Padjadjaran/
Rumah Sakit Dr. Hasan Sadikin Bandung.

\section{Hasil}

Penurunan tekanan intrakranial pada kelompok natrium laktat memperlihatkan distribusi data yang normal dengan penurunan tekanan intrakranial rata-rata $5,92 \mathrm{mmHg}$ atau $19,59 \%$. Dengan mempergunakan uji t berpasangan data tersebut menunjukkan kemaknaan $(p<0,001)$. Tekanan intrakranial sebelum terapi sebesar 30,65 mmHg dan menurun sesudah terapi (Gambar 1).

Kadar natrium pada kelompok natrium laktat saat sebelum dengan sesudah pemberian tidak terdapat perbedaan yang bermakna. Distribusi data memperlihatkan data yang tidak normal, dengan uji Wilcoxon menunjukkan kemaknaan $(p=0,833)$ yang berarti tidak terdapat perbedaan bermakna sebelum dengan sesudah pemberian natrium laktat.

Kadar kalium sebelum dan sesudah pemberian natrium laktat mempunyai distribusi data yang normal, dengan pengujian uji t berpasangan nilai $\mathrm{p}=0,162$ yang berarti tidak terdapat perbedaan bermakna kadar kalium sebelum dengan sesudah pemberian natrium laktat.

Pada uji Shapiro Wilk kadar laktat mempunyai distribusi tidak normal, dengan uji Wilcoxon menunjukkan kemaknaan $p=0,035$. Kenaikan kadar laktat rata-rata sesudah pemberian natrium laktat sebesar 1,19 $\mathrm{mEq} / \mathrm{L}$ atau sebesar 35,1\% (Gambar 2).

Tekanan intrakranial pada penderita yang mendapat terapi manitol dengan uji ShapiroWilk mempunyai distribusi data yang normal. Perbedaan hasil antara sebelum dan sesudah pemberian manitol berdasarkan uji Wilcoxon bermakna $(p=0,005)$. Penurunan tekanan intrakranial rata-rata dengan pemberian manitol sebesar 8,9 $\mathrm{mmHg}$ atau 34,5\% (Gambar 3).

Kadar natrium mempunyai distribusi data yang normal dengan menggunakan uji ShapiroWilk, tetapi data tersebut dengan uji t berpasangan menunjukkan $\mathrm{p}=0,583$ yang berarti tidak terdapat perbedaan yang bermakna kadar natrium sebelum dengan sesudah pemberian manitol.

Tabel Kandungan Totilac yang Digunakan dalam Penelitian

\begin{tabular}{lc}
\hline \multicolumn{1}{c}{ Komposisi } & Jumlah/250 mL \\
\hline Larutan natrium laktat & \\
$(50 \% \mathrm{~b} / \mathrm{v})$ & $28,25 \mathrm{~g}$ \\
Kalium klorida & $75 \mathrm{mg}$ \\
Kalsium klorida & $50 \mathrm{mg}$ \\
Akuades untuk suntikan & sampai $250 \mathrm{~mL}$ \\
\hline
\end{tabular}




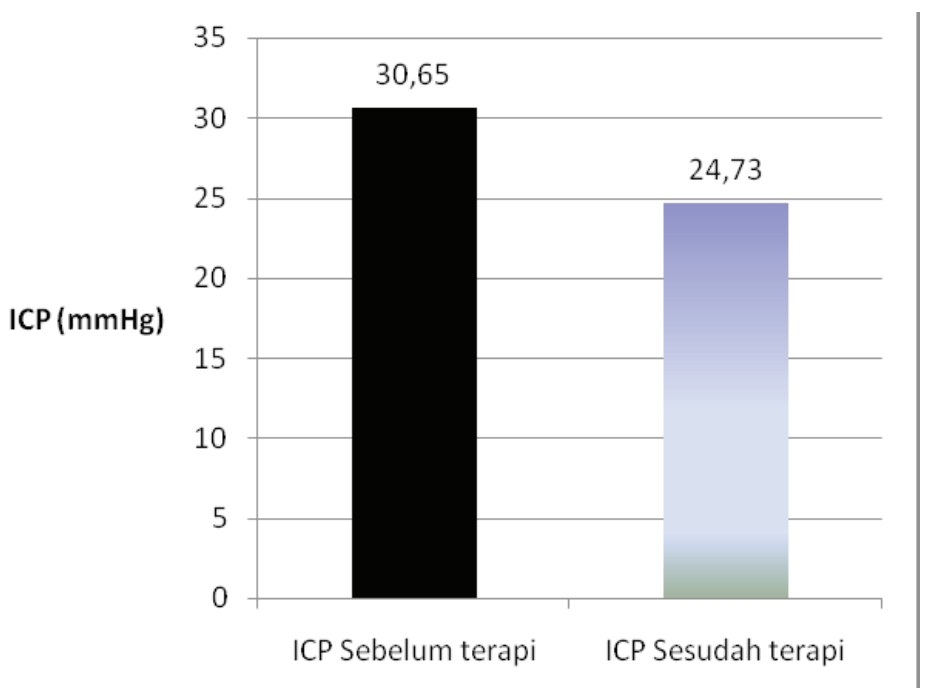

Gambar 1 Perbandingan Tekanan Intrakranial Sebelum dan Sesudah Pemberian Natrium Laktat Keterangan: $\mathrm{ICP}=$ intra cranial pressure

Kadar kalium pada pemberian manitol diuji dengan uji t berpasangan tidak berbeda bermakna sebelum dengan sesudah pemberian manitol $(\mathrm{p}=0,163)$. Kadar laktat pada penderita dengan pemberian manitol mempunyai distribusi data yang normal, dengan uji t berpasangan tidak berbeda bermakna $(\mathrm{p}=0,135)$.

Hasil statistik memperlihatkan bahwa kadar natrium dan kalium kedua kelompok penelitian berbeda bermakna antara sebelum dan sesudah pemberian terapi osmotik. Oleh karena itu, parameter yang dapat dibandingkan hanya tekanan intrakranial dan kadar laktat.

Perbandingan tekanan intrakranial sebelum dengan sesudah penelitian mempunyai distribusi data yang normal dengan uji Shapiro-Wilk, $\mathrm{p}$ natrium laktat $=0,149$ dan $\mathrm{p}$ manitol $=0,323$; kemudian dengan uji independent samples tekanan intrakranial pada kedua kelompok tidak berbeda bermakna $(p=0,417)$ terhadap efek penurunan tekanan intrakranial pada kedua kelompok penelitian.

Perbedaan laktat kedua kelompok penelitian mempunyai distribusi data yang normal, dengan uji Shapiro-Wilk, $p$ natrium laktat $=0,065$ dan $p$ manitol $=0,165$; tetapi berdasarkan uji independent samples berbeda bermakna $(\mathrm{p}=0,016)$.

\section{Pembahasan}

Pada kedua kelompok penelitian ini didapatkan penurunan tekanan intrakranial. Pada kelompok manitol penurunan tekanan intrakranial bermakna sesudah pemberian natrium laktat.

Secara teori penurunan tekanan intrakranial

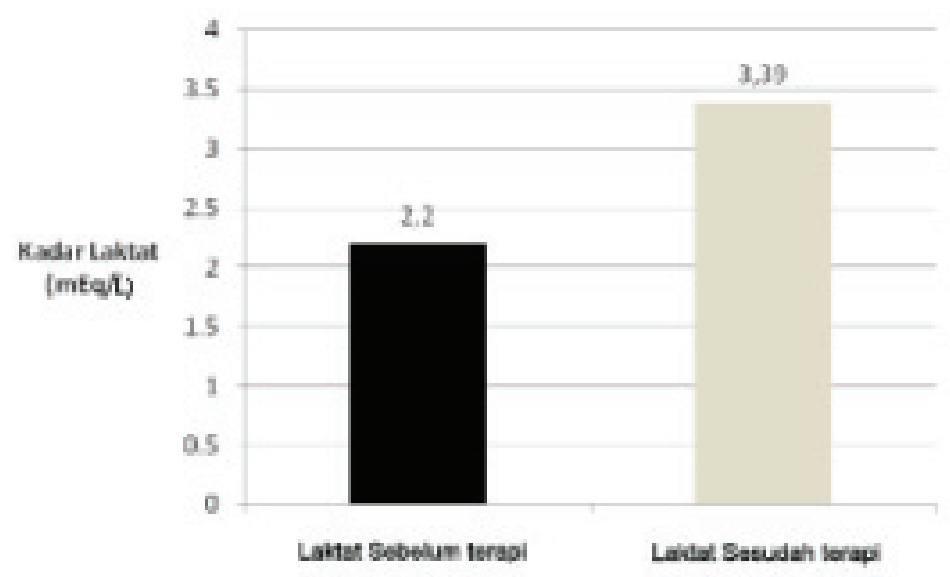

Gambar 2 Kadar Laktat Sebelum dan Sesudah Pemberian Natrium Laktat 


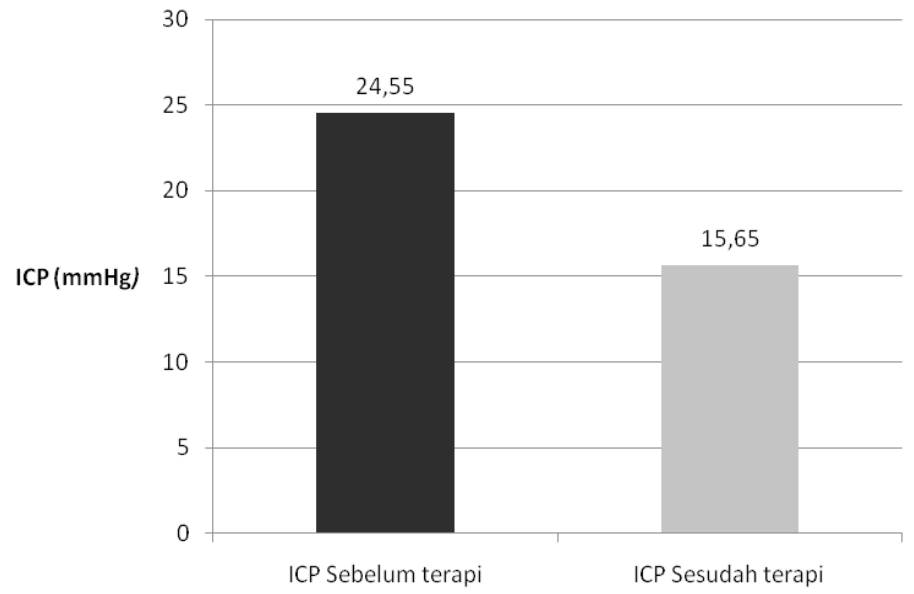

\section{Gambar 3 Tekanan Intrakranial Penderita Sebelum dan Sesudah Pemberian Manitol Keterangan: ICP: intra cranial pressure}

pada pemberian manitol terjadi oleh karena efek osmosis manitol yang menarik air dari parenkim otak ke intravaskular. ${ }^{13}$ Manitol juga menyebabkan vasokonstriksi serta mengurangi produksi cairan serebrospinal yang berpotensi memperkecil peningkatan tekanan intrakranial.

Pada kelompok yang mendapat terapi natrium laktat terjadi penurunan tekanan intrakranial yang bermakna antara sebelum dan sesudah pemberian natrium laktat. Hasil ini sesuai dengan penelitan Rockswold dkk. ${ }^{12}$ serta Chaterjee dkk. ${ }^{15}$ yang menyatakan bahwa larutan natrium hipertonik dapat menurunkan tekanan intrakranial.

Penurunan tekanan intrakranial kemungkinan oleh karena penurunan volume sel otak akibat pemberian natrium laktat. Kemungkinan kedua karena pengisian vaskular menyebabkan kenaikan mean arterial pressure (MAP). Jika autoregulasi masih berfungsi baik, maka kenaikan MAP akan mengakibatkan vasokonstriksi pembuluh darah otak yang akhirnya akan menurunkan volume darah otak, dengan akibat tekanan intrakranial akan menurun. Kemungkinan ketiga karena peningkatan keenceran darah yang memperbaiki autoregulasi serebral. Perkiraan selanjutnya, efek osmotik natrium laktat akan menyebabkan penurunan cairan serebrospinal sehingga tekanan intrakranial menurun. ${ }^{15}$ Penelitian lain memperlihatkan penurunan tekanan intrakranial dapat terjadi oleh karena pengaruh kadar natrium yang lebih tinggi di intravaskular, keadaan ini ditandai dengan penurunan kadar cairan di otak. Hal ini dibuktikan oleh Rockswold dkk. ${ }^{12}$ bahwa penurunan kadar cairan otak berhubungan dengan kenaikan kadar natrium serum selama 72 jam.

Perbedaan penurunan tekanan intrakranial pada kedua kelompok penelitian tidak bermakna. Pada penelitian ini natrium laktat menurunkan tekanan intrakranial sama efektifnya dengan manitol.

Kadar laktat pada kelompok manitol tidak menunjukkan perbedaan bermakna antara sebelum dan sesudah pemberian manitol. Kadar laktat pada kelompok natrium laktat memperlihatkan perbedaan yang bermakna antara sebelum dan sesudah pemberian natrium laktat. Perbandingan kadar laktat pada kelompok manitol dan natrium laktat berbeda bermakna, pada kelompok natrium laktat menunjukkan kadar laktat yang lebih tinggi sesudah pemberian natrium laktat. Pada kedua kelompok penelitian tidak terdapat perbedaan yang bermakna kadar natrium dan kalium antara sebelum dan sesudah pemberian terapi osmotik.

Dari hasil penelitian ini dapat disimpulkan bahwa natrium laktat dan manitol mampu menurunkan tekanan intrakranial pada penderita cedera kepala berat dengan efektivitas sama. Natrium laktat dapat menaikkan kadar laktat pada penderita cedera kepala, sedangkan kadar laktat pada pemberian manitol tidak mengalami perubahan yang bermakna. Selain itu tidak terdapat perbedaan kadar natrium dan kalium pada pemberian natrium laktat dan manitol.

\section{Daftar Pustaka}

1. Clausen F. Delayed cell death after traumatic brain injury [Disertasi]. Uppsala: Acta Universitatis Upsaliensis; 2004.

2. Stiefel MF, Spiotta A, Gracias V, Garuffe AM, Guillamondegui O, Maloney-Wilensky E, dkk. Reduced mortality rate in patients with severe traumatic brain injury treated with brain tissue oxygen monitoring. J Neurosurg. 2005;103;805-11. 
3. Raslan A, Bhrdwaj A. Medical management of cerebral edema. Neurosurg Focus. 2007;22(5):E12.

4. Sorani MD, Manley GT. Dose-response relationship of mannitol and intracranial pressure: a metaanalysis. J Neurosurg. 2008;108:80-7.

5. Ware ML, Nemani VM, Meeker M, Lee C, Morabito DJ, Manley GT. Effects of $23.4 \%$ natrium chloride solution in reducing intracranial pressure in patient with traumatic brain injury: a preeliminary study. Congress of Neurological Surgeon, 2005.

6. Stiefel MF, Udoetuk JD, Spiotta AM, Gracias VH, Goldberg A, Maloney-Wilensky, dkk. Conventional neurocritical care and cerebral oxygenation after traumatic brain injury. J Neurosurg. 2006;105(5):68-75.

7. Anderson RCE, Kan P, Klimo P, Brockmeyer DL, Walker ML, Kestle JRW. Complication of intracranial monitoring in children with head trauma. J Neurosurg 2004;101(2 Suppl):53-8.

8. Qureshi AI, Suarez JI. Hypertonic saline solutions for treatment of intracranial hypertension. Curr Opinion Anaesthesiol. 2000;5:3301-3.

9. Catala-Temprano A, Teruel GC, Lasaosa FJC, Odena MP, Julian AN, Rico AP. Intracranial pressure and cerebral perfusion as risk factors in children with traumatic brain injuries. $\mathrm{J}$ Neurosurg. 2007;106(6 Suppl):463-6.
10. Aarabi B, Mehta R, Eisenberg HW. Trauma. Dalam: Moore AJ, Newel DW, penyunting. Neurosurgery, principles and practice. Edisi ke-3. London: Springer; 2005. hlm. 369460.

11. Greenberg MS. Handbook of neurosurgery. Edisi ke-6. Florida: Greenberg Graphics; 2006.

12. Rockswold GL, Solid CA, Paredes-Andrade E, Rockswold SB, Jancik JT, Quickel RR. Hypertonic saline and its effect on intracranial pressure, cerebral perfusion pressure, and brain tissue oxygen. Neurosurgery. 2009;65(6):1035-42.

13. Stiver SI, Manley GT. Prehospital management of traumatic brain injury. Neurosurg Focus. 2008;25(4):E8.

14. Levasseur JE, Alessandri B, Reinert M, Clausen T, Zhou Z, Altemeni N, dkk. Lactate, not glucose, up-regulates mitochondrial oxygen consumption both in sham and lateral fluid percussed rat brain. J Neurosurg. 2006;59(5):1122-31.

15. Chatterjee N, Chaudhury A, Mukherjee S, Prusty GK, Chattopadhayay T, Saha A. Efficacy of different hypertonic solutes in the treatment of refractory intracranial hypertension in severe head injury patiens; a comparative study of $2 \mathrm{~mL} / \mathrm{kg} 7.5 \%$ hypertonic saline and $2 \mathrm{~mL} / \mathrm{kg} 20 \%$ mannitol. Indian J Neurotrauma. 2007;4(2):101-8. 